\title{
MEMBANGUN APLIKASI PENJUALAN DAN PENGENDALIAN PERSEDIAAN OBAT PADA APOTIK FINNA
}

\author{
Hartoyo Indrajaya Panggabean'1, Nur Alam Arifin², Norma Pravitasari ${ }^{3}$ \\ ${ }^{1,2,3}$ Teknik Informatika, Fakultas Teknik dan Ilmu Komputer, Universitas Indraprasta PGRI Jakarta \\ Jalan Raya Tengah No 80, Kelurahan Gedong, Pasar Rebo, Jakarta Timur

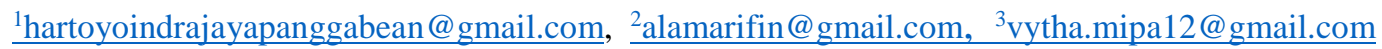

\begin{abstract}
ABSTRAK
Apotik Finna memiliki permasalahan yaitu kesulitan dalam mengontrol stok obat yang ada di Apotik Finna, masih banyak karyawan Apotik Finna berkonsultasi dengan para karyawan dalam ketersediaan dan pendistribusian obat yang terdapat di Apotik Finna. Tujuan merancang suatu sistem informasi transaksi penjualan dan persediaan stok obat ini dengan tujuan untuk memudahkan admin dalam memproses pengolahan data yang ada saat ini. Perangkat aplikasi yang telah dibuat dengan bahasa pemrograman Java NetBeans 8.0.2 dan penyimpanan data pada database MySQL dapat memberikan kelancaran dalam proses menginput dan penyimpanan data-data serta laporan-laporan yang diberikan kepada pemilik apotik. Dengan menggunakan metode pengembangan sistem yaitu Waterfall dalam penelitian ini adalah dengan tahapan-tahapan seperti rekayasa sistem, analisis, desain, coding, testing, dan maintenance. Hasil dari penelitian ini menciptakan suatu sistem informasi pengolahan data dan transaksi penjualan pada Apotik Finna sehingga akan diperoleh informasi yang efektif dan efisien, yaitu membantu memperbaiki kesalahan dalam penulisan data, dan mempermudah dalam pembuatan laporan kepada pemilik apotik baik laporan data obat, data penjualan, data pembelian.
\end{abstract}

Kata Kunci: Aplikasi, Penjualan, Persediaan, Obat, Desktop

\begin{abstract}
The Finna Pharmacy has a problem, namely the difficulty in controlling the stock of drugs at the Finna Pharmacy, there are still many employees of the Finna Pharmacy who consult with the employees in the availability and distribution of drugs in the Finna Pharmacy. The purpose of designing a sales transaction information system and drug stock inventory is to make it easier for admins to process the current data processing. Application tools that have been created using the Java NetBeans 8.0.2 programming language and data storage in the MYSQL database can provide a smooth process for inputting and storing data and reports provided to the pharmacy owner. By using the system development method, namely Waterfall, in this research, the stages are systems engineering, analysis, design, coding, testing, and maintenance. The results of this study create an information system for data processing and sales transactions at Finna Pharmacies so that effective and efficient information will be obtained, namely helping to correct errors in data writing, and making it easier to make reports to pharmacies owners both drug data reports, sales data, data purchase.
\end{abstract}

Key Word: Application, Sales, Stock, Drug, Desktop

\section{PENDAHULUAN}

Perkembangan sistem informasi sangat pesat dan dibutuhkan di beberapa sektor terutama pada sektor kesehatan (Hasti, Si, Setiadi, \& Kom, 2015). Kebutuhan manusia yang senantiasa bertambah telah mendorong manusia untuk dapat menciptakan suatu cara yang efektif dan efisien dalam menyelesaikan pekerjaan disegala bidang terutama bidang kesehatan (Nasution \& Baidawi, 2016). Manfaat serta fungsidari sistem informasi dapat membawa manfaat besar dalam bidang kesehatan. Apotik Finna yang terletak di Jl. Jombang Raya No.B3, RT.1/RW.4, Pondok
Pucung, Pondok Aren, Kota Tangerang Selatan, Banten 15414, dalam menjalankan usahanya memiliki beberapa jenis layanan salah satu layanan tersebut adalah pelayanan pengadaan obat serta transaksi penjualan obat. Proses pengolahan data obat dan transaksi penjualan masih dicatat dalam buku besar dan sering terjadi human error, sehingga kesulitan dalam mengontrol stok obat yang ada di apotik dan hal ini menyebabkan keterlambatan dalam proses laporan kepada pemilik apotik karena sistem yang dikerjakan masih bersifat manual (Andita et al., 2016). 
Sistem transaksi penjualan dan pengendalian persediaan obat merupakan suatu rangkaian kegiatan yang meliputi aspek seleksi dan perumusan kebutuhan, pengadaan, penyimpanan, pendistribusian dan penggunaan obat (Rahmawatie \& Santosa, 2015). Dari penjelasan tersebut dapat didefinisikan bahwa masing-masing pengadaan obat merupakan rangkaian terkait, tujuan dari pengadaan yaitu untuk memperoleh barang atau jasa yang dibutuhkan dalam jumlah yang cukup dengan kualitas harga yang dapat dipertanggung jawabkan, dalam waktu dan tempat tertentu secara efektif dan efisien,menurut tata cara dan ketentuan yang berlaku (Damayanti, 2019).

Dengan permasalahan tersebut, perlu ada nya suatu sistem yang terkomputerisasi dalam penyelesaiannya. Sistem adalah seperangkat ajaran, gagasan, atau asas yang terorganisasi biasanya dimaksudkan untuk menjelaskan pengaturan atau cara kerja dari keseluruhan yang sistematis (Sutabri, 2012). Sistem merupakan suatu kumpulan objek yang meliputi hubungan antara objek tersebut, serta hubungan antara sifat yang mereka punya (Tyoso, 2016). Pembangunan sistem adalah sekumpulan aktivitas yang menggambarkan secara rinci bagaimana sistem akan berjalan. Hal itu bertujuan untuk menghasilkan produk perangkat lunak yang sesuai dengan kebutuhan user (Satzinger, J. W., Jackson, R. B., Burd, n.d.).

Solusi dari permasalahan yang dihadapi Apotik Finna perlu adanya suatu sistem informasi dalam memproses pengendalian stok obat dan transaksi penjualan. Diharapkan dengan dirancangnya sistem ini dapatmempermudah serta mempercepat penyelesaian kegiatan pengadaan obat sehingga mencapai hasil yang optimal dan pentingnya pengolahan data dengan menggunakan komputer sebagai alat bantu menghasilkan informasi sistem transaksi penjualan dan pengendalian stok obat tersebut.

Diharapkan dengan adanya suatu sistem informasi dapat menangani permasalahan yang ada di perusahaan tersebut. Sistem adalah setiap sesuatu terdiri dari obyek-obyek, atau unsur-unsur, atau komponen-komponen yang bertata kaitan dan bertata hubungan satu sama lain, sedemikian rupa sehingga unsur-unsur tersebut merupakan satu kesatuan pemrosesan atau pengolahan yang tertentu. (Prasojo, 2011)

Aplikasi ini dapat memudahkan pekerjaan Admin apotik dalam melaksanakan pembuatan laporan dan mempercepat dalam proses data transaksi penjualan dan pengendalian persediaan obat pada Apotik Finna.

\section{METODE PENELITIAN}

Peneliti menggunakan metode Research and Development daam penyelesaian penelitian ini. (Sugiyono, 2016). Dalam pelaksanaan R\&D, ada beberapa metode yang digunakan yaitu metode deskriptif, evaluatif dan eksperimental. Metode penelitian deskriptif digunakan dalam penelitian awal untuk menghimpun data tentang kondisi yang ada yaitu penulis membutuhkan data-data yang dapat menunjang tercipta nya suatu sistem informasi penjualan obat seperti data obat, data jenis obat, data supplier dan data penjualan terdahulu yang masih tersimpan secara manual didalam buku besar. Metode evaluatif digunakan untuk mengevaluasi proses ujicoba pengembangan suatu produk, dalam proses ini penulis melakukan ujicoba terhadap suatu sistem yang telah dirancang agar tidak ada terjadi kesalahan dalam proses penginputan data serta pelaporan bulanan kepada pemilik apotik. Dan metode eksperimen digunakan untuk menguji keampuhan dari produk yang dihasilkan, dalam proses yang terakhir ini perlu dilakukan pengujian akhir yang diharapkan bahwa sistem yang dirancang oleh penulis dapat berjalan dengan baik dan sesuai dengan kebutuhan dan terfokus pada proses transaksi penjualan dan persediaan obat pada Apotik Finna.(Putra, 2011).

\section{HASIL DAN PEMBAHASAN}

\section{Analisa Permasalahan}

Dari hasil penelitian yang penulis lakukan maka penulis dapat menganalisa permasalahan yang ada pada pengadaan obat yaitu:

1. Proses penerimaan dan pengadaan obat yang masuk masih dilakukan secara manual dengan menggunakan media kertas.

2. Sistem pengadaan obat yang belum terkomputerisasi menyebabkan lambannya pekerjaan para pegawai dalam melayani masyarakat sehingga tidak efektif dan efisien. 
3. Kurangnya sumber daya manusia yang memahami sistem komputerisasi menjadi suatu penyebab belum dibuatnya sistem informasi penjualan dan persediaan obat pada Apotik Finna.

\section{Alternatif Penyelesaian Masalah}

Berdasarkan masalah-masalah yang dihadapi dalam penjualan dan persediaan obat di Apotik Finna, maka penulis memberikan alternatif penyelesaian masalahnya, yaitu:

1. Perancangan sistem informasi penjualan dan persediaan obat yang terkomputerisasi sehingga dapat dihasilkan informasi yang cepat, tepat dan akurat.

2. Perancangan database untuk sistem pengadaan obat sehingga penyimpanan data obat tidak menggunakan media kertas lagi melainkan berupa hardisk atau media penyimpanan elektronik lainnya.

3. Membuat sistem informasi penjualan dan persediaan obat yang mudah dipahami oleh setiap karyawan di Apotik Finna.

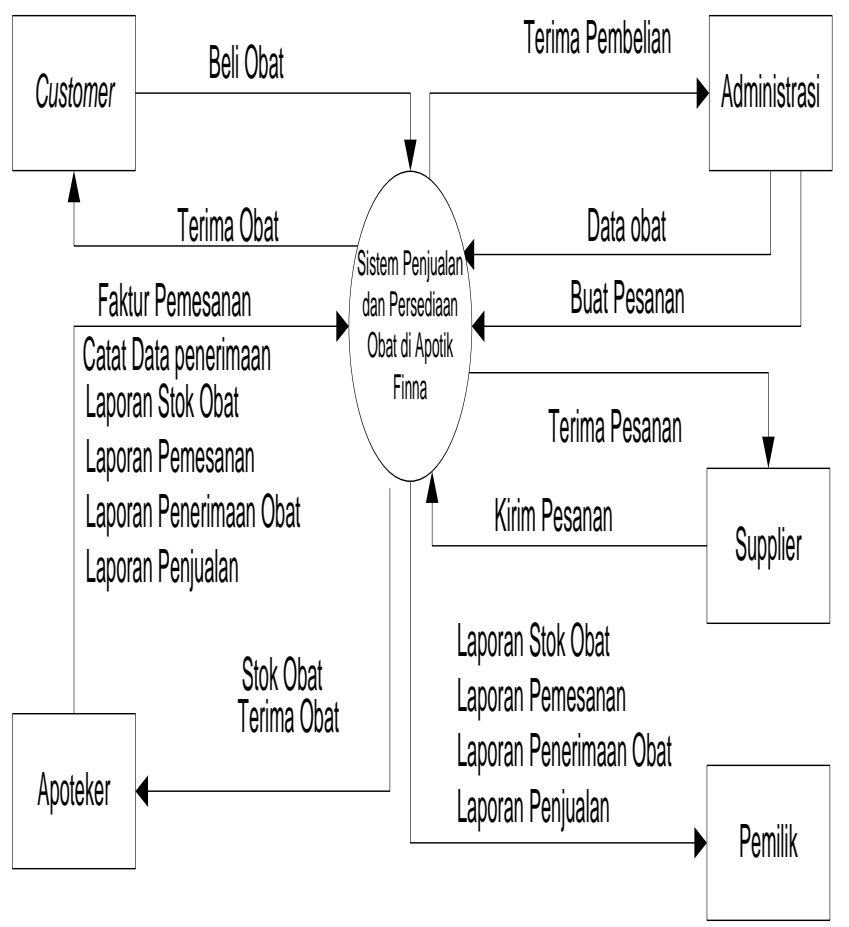

Gambar 1. Diagram Konteks

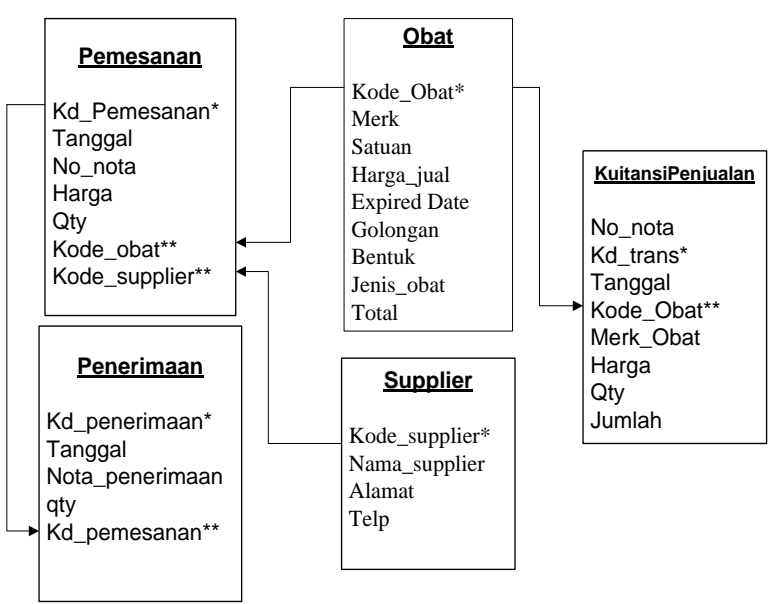

Gambar 2. Normalisasi

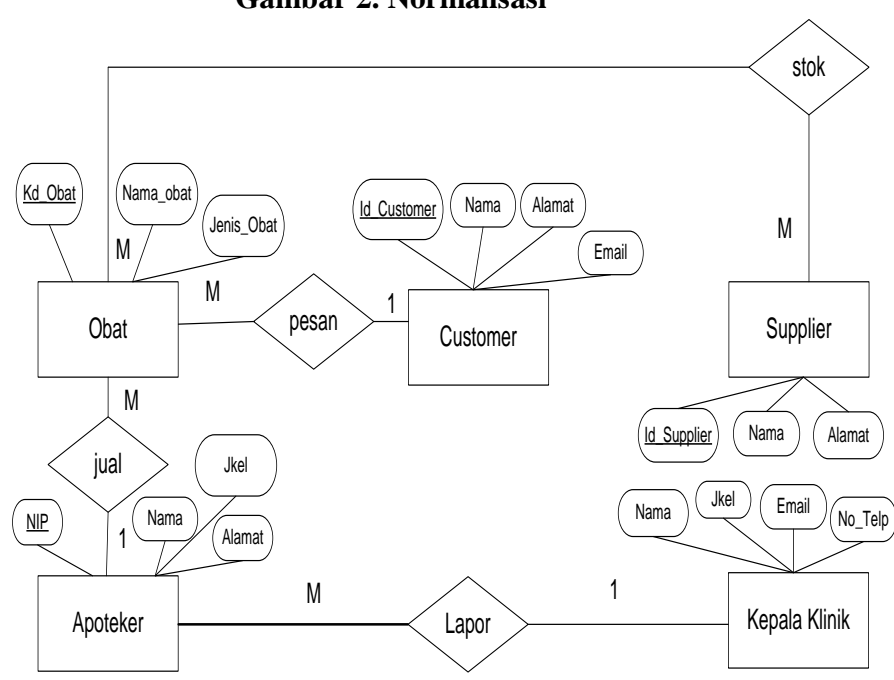

Gambar 3. ERD (Entity Relationship Diagram)

Berikut adalah tampilan layar dan hasil pengujian pada software program yang telah di buat dengan bahasa pemrograman Java.

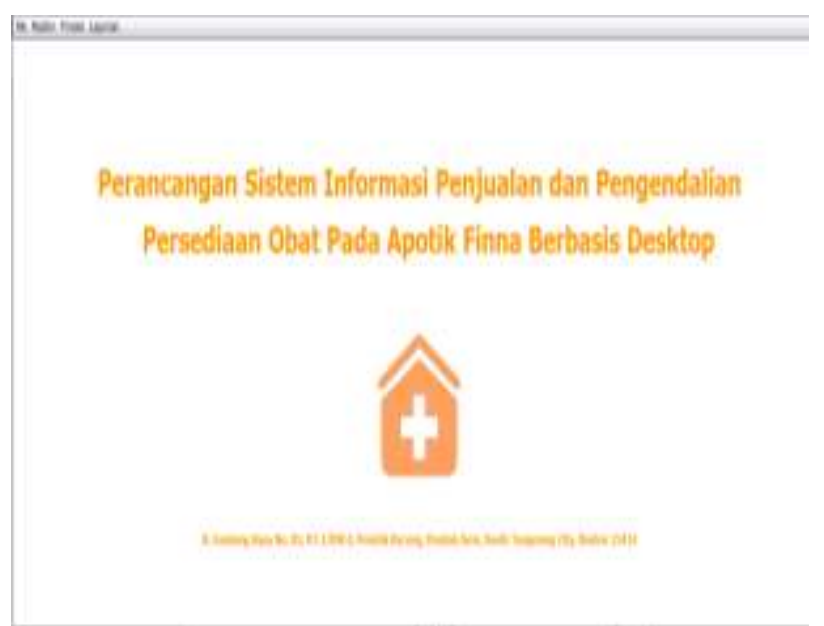

Gambar 4. Form Menu Utama 
Layar di atas menampilkan tampilan Menu Utama pada Aplikasi Penjualan dan Persediaan Obat Pada Apotik Finna Berbasis Desktop. Pada layar utama tersedia menu bar yang terdiri dari master data yang digunakan untuk memasukkan data yang berkaitan dengan data obat, data supplier, data pemesanan, data penerimaan, data penjualan dan laporan-laporan.

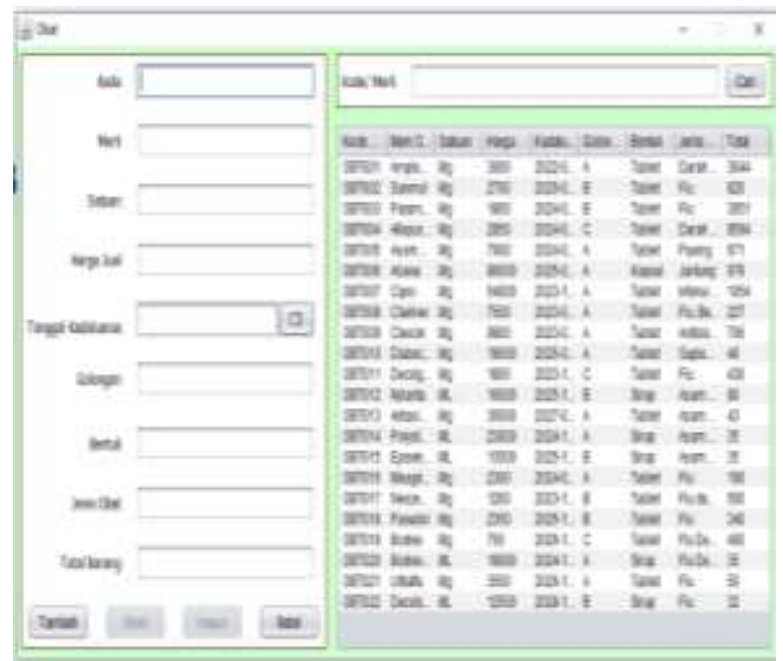

Gambar 5. Form Data Obat

Layar di atas menampilkan tampilan form data obat. Pada layar form data obat untuk menginput data obat yang terdiri dari Kode_Obat, Merk, Satuan, Harga Jual, Jenis Obat, Golongan, Bentuk, Total Barang.

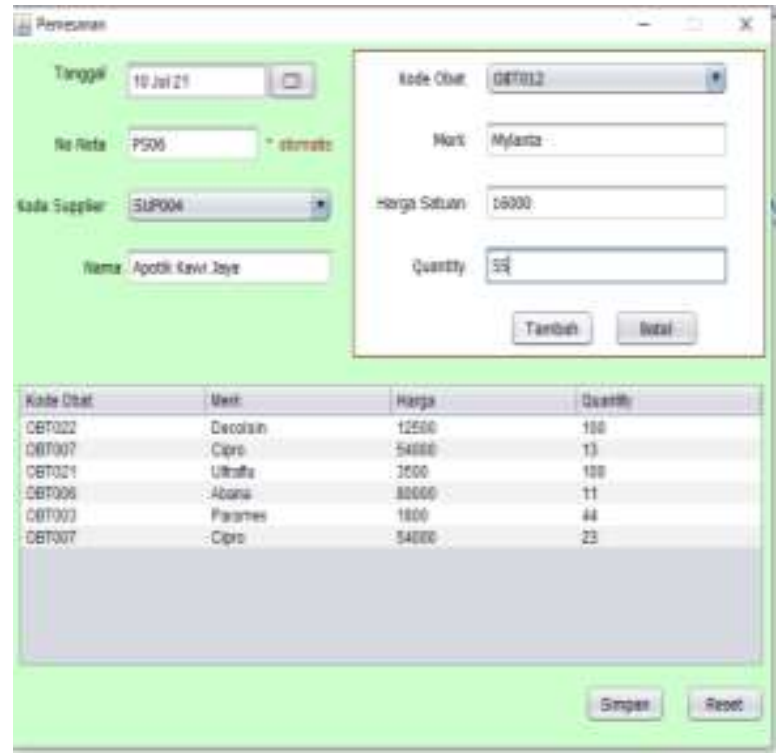

Gambar 6. Form Data Pemesanan
Layar di atas menampilkan tampilan form data pemesanan. Pada layar form data pemesanan untuk menginput data pemesanan yang terdiri dari Tanggal, No Nota, Kode Supplier, Nama, Kode Obat, Merk, Harga Satuan, Quantity.

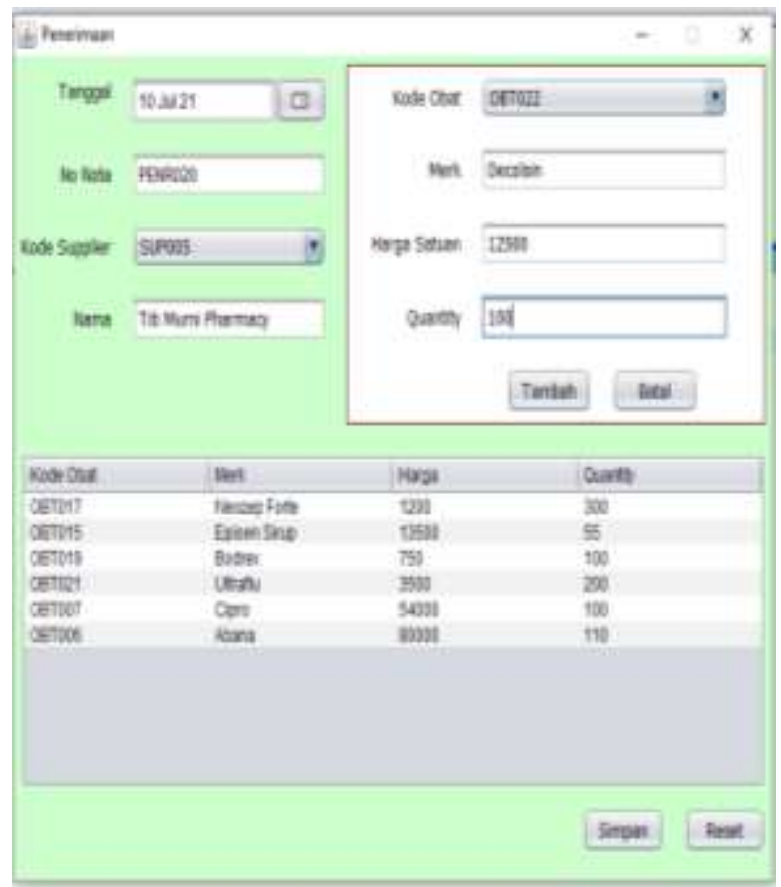

Gambar 7. Data Form Data Penerimaan

Layar di atas menampilkan tampilan form data penerimaan. Pada layar form data penerimaan untuk menginput data penerimaan yang terdiri dari Tanggal, No Nota, Kode Supplier, Nama, Kode Obat, Merk, Harga Satuan, Quantity.

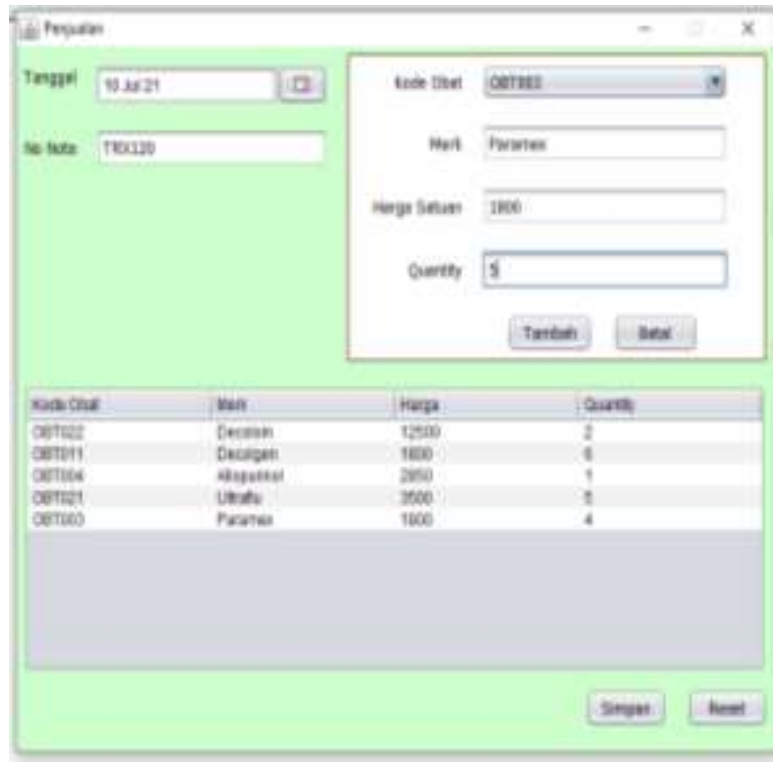

Gambar 8. Form Data Transaksi Penjualan

743 | Membangun Aplikasi Penjualan dan Pengendalian Persediaan Obat pada Apotik Finna 
Layar di atas menampilkan tampilan form data penjualan. Pada layar form data penerimaan untuk menginput data penerimaan yang terdiri dari Tanggal, No Nota, Kode Supplier, Nama, Kode Obat, Merk, Harga Satuan, Quantity.

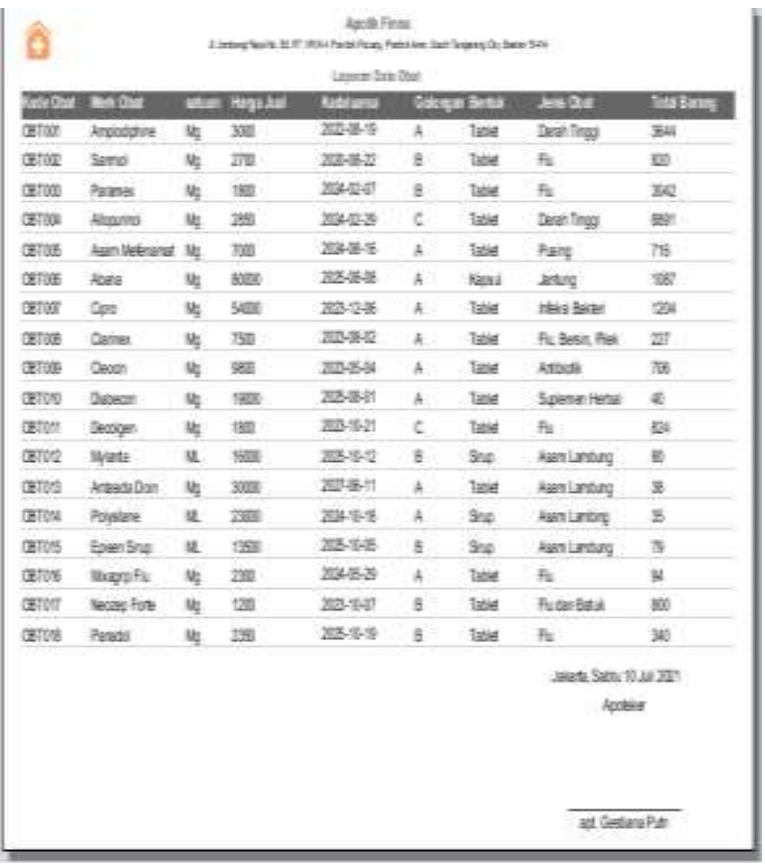

Gambar 10. Laporan Stok Obat

Layar di atas menampilkan tampilan form laporan data stok obat. Pada layar form data stok obat digunakan untuk mengecek laporan stok obat terdiri Kode_Obat, Merk, Satuan, Harga Jual, Jenis Obat, Golongan, Bentuk, Total Barang.

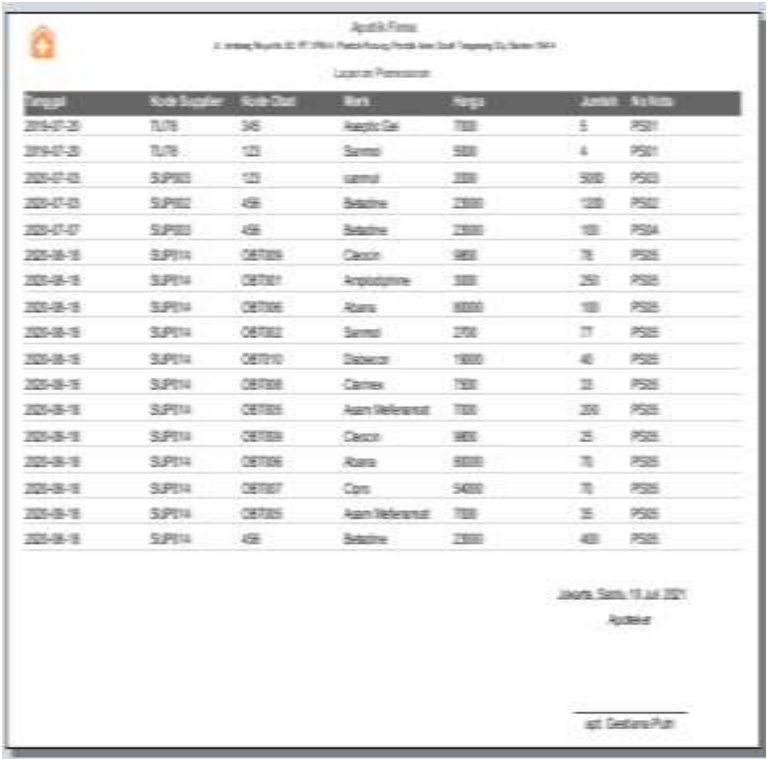

Gambar 11. Laporan Data Pemesanan
Layar di atas menampilkan tampilan form laporan pemesanan. Pada layar form data pemesanan digunakan untuk mengecek laporan pemesanan terdiri Tanggal, No Nota, Kode Supplier, Nama, Kode Obat, Merk, Harga Satuan, Quantity.

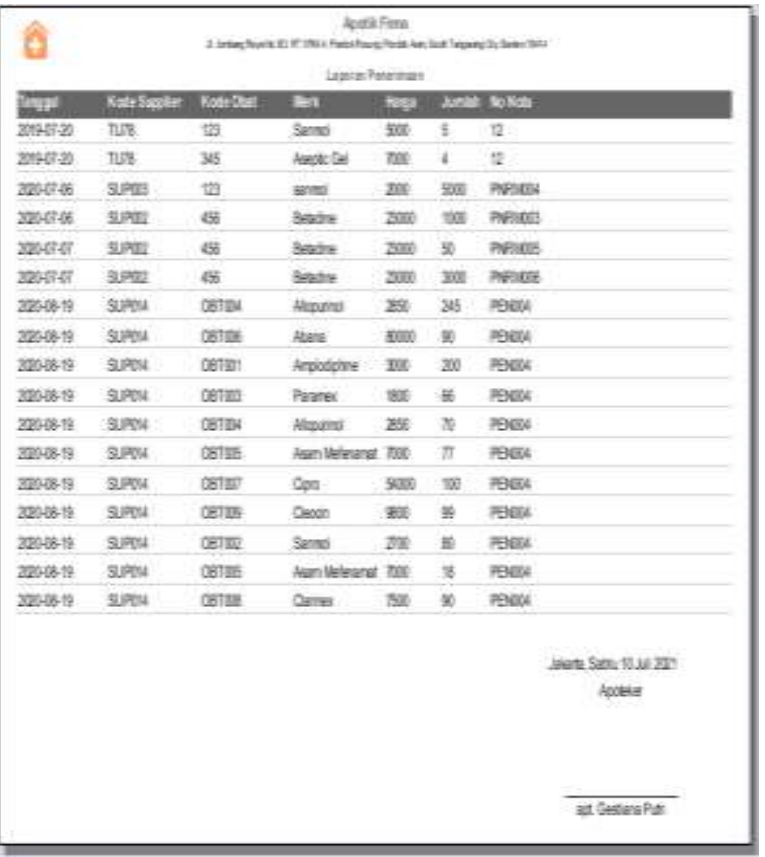

Gambar 12. Laporan Data Penerimaan

Layar di atas menampilkan tampilan form laporan penerimaan. Pada layar form data penerimaan digunakan untuk mengecek laporan penerimaan terdiri Tanggal, No Nota, Kode Supplier, Nama, Kode Obat, Merk, Harga Satuan, Quantity.

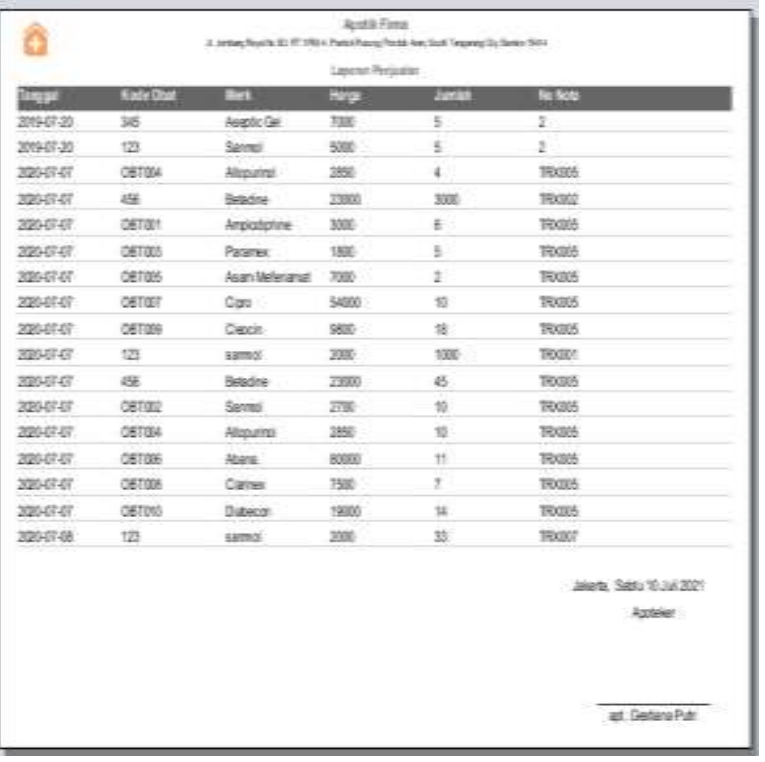

Gambar 13. Laporan Data Penjualan

744 | Membangun Aplikasi Penjualan dan Pengendalian Persediaan Obat pada Apotik Finna 
Layar di atas menampilkan tampilan form laporan penjualan. Pada layar form data penjualan digunakan untuk mengecek laporan penjualan terdiri Tanggal, No Nota, Kode Supplier, Nama, Kode Obat, Merk, Harga Satuan, Quantity.

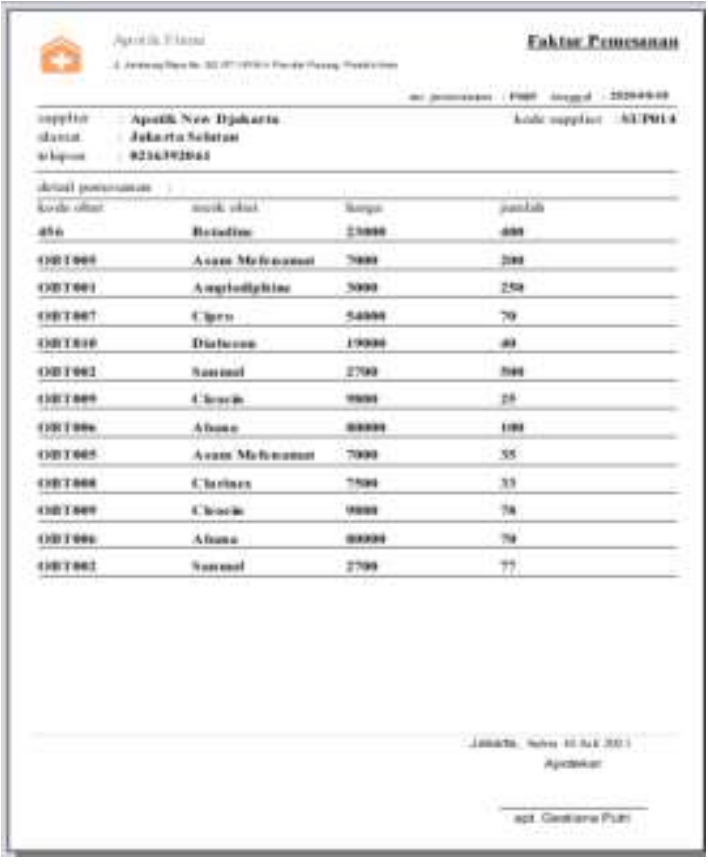

Gambar 14. Faktur Pemesanan

Layar di atas menampilkan tampilan faktur pemesanan. Pada layar faktur pemesanan terdiri dari No Pemesanan, Tgl Pemesanan, Kode Supplier, Nama Supplier, Alamat, No Telp, Kode Obat, Nama Obat, Harga dan Jumlah.

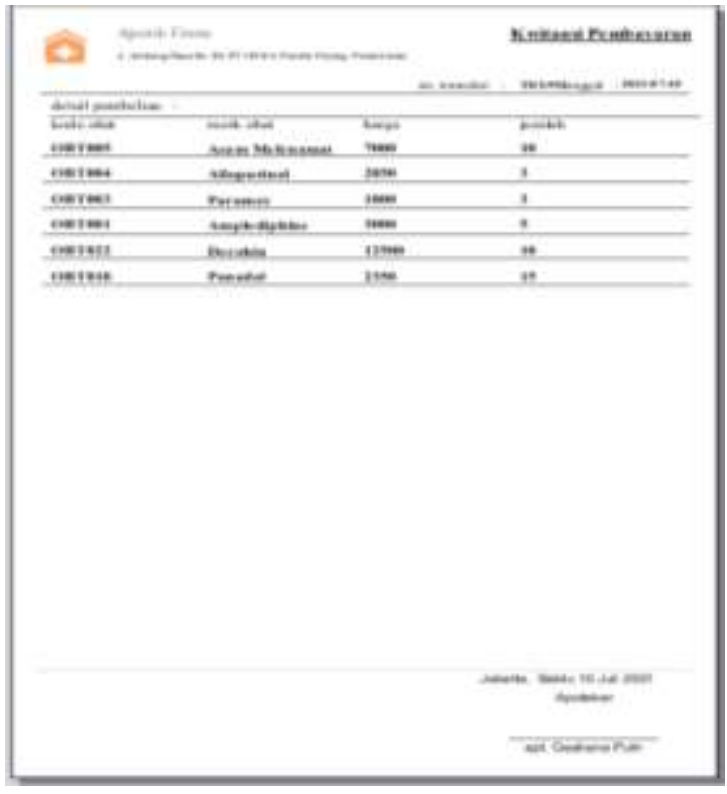

Gambar 15. Kuitansi Pembayaran
Layar di atas menampilkan tampilan kuitansi pembayaran. Pada layar kuitansi pembayaran terdiri dari No Transaksi, Tanggal, Kode Obat, Merk Obat, Harga, dan Jumlah.

\section{SIMPULAN DAN SARAN}

Sistem komputerisasi maka Apotik Finna akan mengalami peningkatan dalam menangani proses seluruh data pengadaan stok obat dan penjualan obat dibandingkan sistem manual. Pengolahan data pengadaan stok obat dan transaksi penjualan, serta keamanan terhadap Apotik Finna data lebih terjamin. Aplikasi yang dirancang memudahakan administrator untuk memantau atau mengontrol data yang ada dalam database.

Sarannya adalah karyawan pada Apotik Finna diberikan training/pelatihan yang cukup terhadap sistem tersebut.

\section{DAFTAR PUSTAKA}

Andita, R., Nurul, P., Rachmatullah, P., Akbar, S., Permata, S., \& Mulyaningsih, S. (2016). Analisis dan Perancangan Sistem Informasi Pelayanan Obat di Apotek Generik. Jurnal Edukasi Dan Penelitian Informatika (JEPIN). https://doi.org/10.26418/jp.v2i1.15463

Damayanti, E. (2019). Sistem Informasi Penjualan Obat Pertanian Berbasis Web pada Toko BUTANI Blora. Walisongo Journal of Information Technology. https://doi.org/10.21580/wjit.2019.1.2.4520

Hasti, N., Si, S., Setiadi, D., \& Kom, S. (2015). Sistem Informasi Penjualan Dan Pembelian Obat (Studi Kasus: Apotek Emulinda Bandung) Novrini Hasti, S.Si, MT dan Dani Setiadi, S.Kom. Jurnal Teknologi Dan Informasi (JATI).

Nasution, A., \& Baidawi, T. (2016). Sistem Informasi Penjualan Obat Berbasis Web pada Apotek Perwira Jaya Bekasi. Informatics for Educators and Professionals.

Prasojo, M. (2011). Pengantar Sistem Informasi Manajemen. bandung: CV. Remadja Karya.

Putra, N. (2011). Research and Development, Penelitian dan Pengembangan: Suatu Pengantar. Jakarta: PT Raja Grafindo Persada. 
Rahmawatie, E., \& Santosa, S. (2015). Sistem Informasi Perencanaan Pengadaan Obat Di Dinas Kesehatan Kabupaten Boyolali. Pseudocode. https://doi.org/10.33369/pseudocode.2.1.4552

Satzinger, J. W., Jackson, R. B., Burd, S. D. (n.d.). System Analysis and Design in A Changing World. USA: Cengage Learning.

Sugiyono. (2016). Metode Penelitian Kuantitatif, Kualitatif dan $R \& D$. Bandung: PT Alfabet.

Sutabri, T. (2012). Analisis Sistem Informasi. Yogyakarta: Andi.

Tyoso, J. S. P. (2016). Sistem Informasi Manajemen. Yogyakarta: DeePublish. 